\title{
Music and dance in mammals
}

\author{
WILLIAM Z. LIDICKER, JR. \\ Professor of Integrative Biology Emeritus and Curator of Mammals Emeritus, Museum of Vertebrate Zoology, University of \\ California, Berkeley, California 94720-3160
}

\begin{abstract}
A long-standing belief among humans is that the behaviors we call making music and dancing are thought to be strictly human activities. Rapidly accumulating evidence, however, tells a different story. Both music and dance are characterized by sensitivity to and moving in response to rhythms. Among humans, these two behaviors are ubiquitous in all living cultures and can be traced back in our Neanderthal ancestors at least 50,000 years, and probably much longer. It is well established that in humans these two rhythmic behaviors play important social functions, and in recent years have been increasingly noted as well for their health benefits. All of this has called attention to similar behaviors in non-humans. Many examples have been noted among mammals, birds, reptiles, amphibians and even bony fish. Neurologists became interested in understanding the neural mechanisms for these rhythmic behaviors and found that rhythmic behaviors are organized in one of the most ancient parts of the vertebrate brain, namely the subcortical posterior parietal cortex which is located just on top of the uppermost ending of the spinal cord. This anatomy was then found to be the same in almost all vertebrates going back in history for many millions of years to the bony fish. So, now it is understandable why music and dance are so widespread among the vertebrates and why there seems to be the potential for these rhythmic behaviors to appear in most of the vertebrates. This discovery also emphasizes the potential availability of the beneficial effects of these behaviors. Needless to say, there is also the prospect of an emerging opportunity for much exciting and important research on mammals.
\end{abstract}

Una creencia antigua entre los humanos es que los comportamientos que llamamos hacer música y bailar se consideran actividades estrictamente humanas. Sin embargo, la evidencia que se acumula rápidamente cuenta una historia diferente. La música como la danza se caracterizan por la sensibilidad y el movimiento en respuesta a los ritmos. Entre los humanos, estos dos comportamientos son ubicuos en todas las culturas vivas y se remontan a nuestros antepasados neandertales, al menos 50,000 años, y probablemente mucho más. Está bien establecido que en los humanos estos dos comportamientos rítmicos desempeñan funciones sociales importantes y en los últimos años también se han observado cada vez más por sus beneficios para la salud. Todo esto ha llamado la atención sobre comportamientos similares en los no humanos. Se han observado muchos ejemplos entre mamíferos, aves, reptiles, anfibios e incluso peces óseos. Los neurólogos se interesaron en comprender los mecanismos neurales para estos comportamientos rítmicos y descubrieron que los comportamientos rítmicos están organizados en una de las partes más antiguas del cerebro de los vertebrados, a saber, la corteza parietal posterior subcortical que se encuentra justo en la parte superior del extremo superior de la medulla espinal. Se descubrió que esta anatomía es la misma en casi todos los vertebrados que se remontan a la historia durante millones de años hasta los peces óseos. Por lo tanto, ahora es comprensible por qué la música y la danza están tan extendidas entre los vertebrados y por qué parece existir la posibilidad de que estos comportamientos rítmicos aparezcan en la mayoría de los vertebrados. Este descubrimiento también enfatiza la disponibilidad potencial de los efectos beneficiosos de estos comportamientos. No es necesario decir que también existe la posibilidad de una oportunidad emergente para realizar investigaciones muy interesantes e importantes sobre mamíferos.

Key Words: health benefits; Neanderthals; neural integration; posterior parietal cortex; rhythms; social behavior; vertebrates.

C 2019 Asociación Mexicana de Mastozoología, www.mastozoologiamexicana.org

\section{Introduction}

Music and dance are still widely considered to be exclusive behaviors of humans (Hanna1983). In this essay I will argue that this is not a realistic conclusion, and in fact these two behaviors greatly pre-date the origins of Homo sapiens. Of course there is no argument that humans have developed music and dance to amazing levels of complexity unmatched by any other species on this planet. It is appropriate to begin with some dictionary definitions in order to make sure that there are not misunderstandings or unintended misinterpretations about our subject matter.

Music - The art and science of combining vocal and/or instrumental sounds or tones in varying melodies, harmonies, rhythms, and timber. In some definitions the following phrase is added: "so as to express emotionally expressive compositions." The art of arranging tones in orderly sequences so as to produce a unified and continuous composition.
Dance - To move the body and feet in rhythm, ordinarily to music. To move rhythmically to music using improvised or prescribed gestures and steps. These are obviously human-oriented definitions, but we can use them cautiously.

\section{Mammals}

These two behaviors are strongly associated with social contexts and are powerful signals of emotional states. In the human lineage they can be traced back in time at least to the Neanderthal culture (Mithin 2006). This book is subtitled, "the origin of music, language, mind, and body," and the author brings a formidable interdisciplinary background to bear on developing a plausible history for how and when humans developed verbal language. He makes the argument that non-verbal gestures, rhythmic sensitivity, and musical sounds are necessary precursors to the evolution of verbal language. Moreover, Neanderthal remains have revealed no archaeological evidence of symbolic reasoning 
and hence they could not have had a verbal language since words are symbolic phenomena (Lidicker 2012). It is now incontrovertible that before vocal language evolved music and dance were, and continue to be powerful means of communication and coordination among humans (Balter 2004). An interesting historical tidbit of these early times was that the earliest known flute was aged at 32,000 years (Balter 2004).

The overall and continuing importance of music and dance in human evolution is indicated by the fact that virtually all existing human cultures include music and dance. In an early paper on this subject, Balter (2004) emphasizes the importance of music in this process, but hardly acknowledges the critical role of dance as well. Since then it has become increasingly apparent that both these activities are adaptive, especially in social contexts. They strengthen social bonding, group recognition, mate finding, and are powerful signals of emotional states. Rapidly increasing evidence also points to significant health benefits from exercise (Hogan 2008; Gitler 2011, Spires-Jones and Ritchie 2018), and this is particularly the case for dance which combines the benefits from exercise with those from music. For example, dancers have been shown to have better immune systems, reduced stress, and improved moods (Sarich 2013), and even premature infants have improved vital signs if provided with music (Loewy 2013). Schellenberg (2004) makes the case that music lessons improve IQ scores. Brown and Parsons (2008) emphasize the vital importance of rhythmic movements (dance) in this pre-vocal language stage of human history. Rapidly accumulating evidence also reveals that dance is a particularly effective choice for health-related exercises, and also has positive effects on the brain (Verghese et al. 2003; Powers 2007). It is no accident that orchestral conductors with their intricate knowledge and exposure to music combined with often vigorous accompanying rhythmic movements typically have unusually long life spans. The healthful effects of music and dance were known to the classical Greeks. Given that music and dance are important to humans going back at least to the Neanderthal era, we now need to consider the extent to which these skills go farther back in time and specifically to explore the extent to which they may be found in mammals generally. One theory that has been around for a long time is that since mammals, except for monotremes, are viviparous and so have the ubiquitous experience of developing in association with their mother's heart beat and breathing rhythms. Beyond that, newborns also often experience rhythmic vocalizations as well as rhythmic movements of their mothers, and close body contact through nursing and other parental behaviors. Human infants certainly have good rhythm perception. In general, rhythmic experiences lead to rhythmic sensitivities. Moreover, most mammals make vocalizations, although in many cases these sounds are in high frequencies and not audible to humans. Nevertheless, these sounds have rhythmic musical properties and are subjects of increasing research interest.
Our first step for finding evidence in support of our general conclusion that music and dance are widespread in mammals is to look at our closest non-human relatives, the great apes. Rapidly growing evidence leads to the conclusion that all of these species have recognizable rhythmic activities and sensitivities, including vocalizations (Williams 1967; King 2009). A case in point is that chimpanzees (Pan troglodytes) are clearly capable of keeping time to music (Gannon 2014; Kotz 2014; Large and Gray 2015), and of listening critically to music (Gannon 2014). In one experiment a chimp expressed a clear preference for music from India and West Africa and disdain for Western music (Mingle 2014). Also, bonobos, a close chimp relative (Pan paniscus), can entrain drum beats with head bobbing (Large and Gray 2015).

Other mammals that have been observed to respond to musical rhythms include gorillas, dogs (Bloom 2004; Kaminski et al. 2004), sea lions (Zalophus californicus; Cook et al. 2013), singing mice (Scotinomys; Okobi et al. 2019), house mice (Mus musculus; Spires-Jones and Ritchie 2018), and elephants. Also, almost all bats have complex vocalizations most of which are at too high frequencies for humans to hear. It is therefore reasonable to conclude with confidence that mammals in general seem to be endowed with rhythmic sound capabilities and sensitivities. If they respond with body movements to these rhythms, as many seem to do, we can consider this dance.

\section{Non-mammals}

Although our focus here is on mammals, it turns out that our general conclusion is significantly reinforced if we look beyond mammals to other vertebrates. While phylogenetically distant from mammals, birds are an obvious example of widespread music and dance in non-mammal vertebrates (Gess 2007; Pennisi 2012). With the exception of the ratites, birds in general vocalize, mostly with rhythmic components. A particularly spectacular example is the complex duetting exhibited by some tropical species in which the two members of a pair alternate inserting musical components into a single integrated song (Fortune et al. 2011). One aspect of this interesting life history feature is that females of a duetting pair have significantly fewer offspring that are fathered by a different male than her mate (extra-pair copulations) than do non-duetting individuals (Douglas et al. 2012). Some birds have dance-like behaviors in some cases performed on an arena or lek. These behaviors serve for males to attract females with their dance and vocal skills. In general bird vocalizations involve mate choice, territorial defense, and emotional signaling.

Among reptiles, many lizards display rhythmic head bobbing behaviors. Frog choruses are classic examples of critically important vocal communications. Less well studied are rhythmic sounds made by air bladders in bony fish. The general conclusion is that forms of music and dance are widespread in vertebrates going back in evolution to bony fish (Actinopterygii and Sarcopterygii). It has 
recently become clear that brains love rhythms. Routine brain activities include integration of information both from an individual's body and sensory inputs from the environment. Often this integrated information then requires rapid behavioral responses. This is a complex challenge. It turns out that all of this coordination is enhanced by rhythmic neuronal communication. Signals from individual neurons are quickly organized into functional groups (Freeman 1951; Canolty 2010). Perhaps this explains why dancing with all of its varied rhythms is much easier and more natural for brains than would be organizing non-rhythmic tasks.

\section{Vertebrates in general}

Finally, we come to the most persuasive evidence that supports the widespread importance of various forms of music and dance in mammals. As it turns out, it is not only mammals in which music and dance is widespread, but most of the vertebrates as well. Recent neurophysiological research on the brain (Bass et al. 2008; Margoliash and Hale 2008) has discovered that the location in the brain where rhythmic behaviors are organized is not in the cerebral cortex where you might expect to find it, but instead it is in the most primitive subcortical parietal part of the brain located just above the anterior end of the spinal cord (Posterior parietal cortex). This most revealing finding says clearly that rhythmic organization is an ancient component of vertebrate evolution. This new insight means that vertebrate vocalizations (many of which would qualify as music) and rhythmic body movements (many of which would qualify as dance) had a common ancestor more than 400 million years ago. Another corollary of this anatomy is that music and dance are functionally coordinated but are disconnected from verbal language which is organized in more recent or higher parts of the brain. This arrangement explains why persons with brain damage affecting speech will likely not have any diminution of functions involving music and dance. Conversely, damage to the subcortical location of music and dance coordination will not damage verbal language functioning. A related consequence is that music and dance skills can penetrate the "fog" of dementia or even Alzheimer's disease which are centered in more advanced parts of the brain. Lastly, it is increasingly evident that human infants can mimic rhythmic movements, and show enjoyment in doing this (Phillips-Silver and Trainor 2005). All of this means that organized rhythmic behavior is potentially present in vertebrates going back in time to bony fish (Actinopterygii and Sarcopterygii). Mammals certainly have the neuronal architecture for indulging in rhythmic sound production (singing) as well as rhythmic body movements (dance), and many species seem to have taken advantage of this potential capability.

Some of the evidence for music and dance in nonhuman mammals presented here can be considered as anecdotal. This could tempt skeptical readers to conclude that the evidence for widespread rhythmic sensitivities in mammals is unreliable or unimportant. On the other hand, even anecdotal evidence clearly supports the conclusion that the neural apparatus for rhythmic sensitivities is present in diverse species of mammals, and hence is available for exploitation. Furthermore, most mammals have the capability of making vocal sounds, and hence the potential for rhythmic utterings is real. Given also the evidence that music and dance have important social and health benefits opens the possibility for major research opportunities. Let's take advantage of this relatively little-explored component of mammalogy.

\section{Literature Cited}

Balter, M. 2004. Seeking the key to music. Science 306:11201122.

Bass, A. H., E. H. GILland, and R Baker. 2008. Evolutionary origins for social vocalization in a vertebrate hindbrain-spinal compartment. Science 321: 417-421.

BLоOM, P. 2004. Can a dog learn a word? Science 304: 1605-1606. BROWN, S., AND L. M. PARSONs. 2008. Recent brain imaging studies reveal some of the complex neurochoreography behind our ability to dance: the neuroscience of dance. Scientific American (July): 78-83.

Canolty, R. J. 2010. Oscillatory phase coupling coordinates anatomically dispersed functional cells. Proceedings of the National Academy of Sciences B. 107(40):17356-17361.

COoK, P., ET AL. 2013. California sealion (Zalophus californicus) can keep the beat: motor entrainment for rhythmic auditory stimuli in a non vocal mimic. Journal of Comparative Psychology 127: 412-427.

Douglas, S. B., D. D. Heath, and D. J. Mennill. 2012. Low levels of extra-paternity in a Neotropical duetting songbird, the Ruffous- and -White wren (Thryothorus rufalbus). The Condor $114: 393-400$.

Fortune, E. S., C. Rodriguez, D., D. li, G. F. Ball, and M. L. Coleman. 2011. Neural mechanisms for the coordination of duetting in singing in wrens. Science 334: 666-670.

Freeman, W. J. 1995. Societies of brains: A study in the neuroscience of love and hate. Lawrence Erdbaum Associates,Pub., Hillside, N.J., 204 pp.

Gannon, M. 2014. Chimps reveal their taste in music. Journal of Experimental Psychology: Animal learning and cognition. vol. 139?:

GEss, A. 2007. Birds like music, too. Science 317: 1864.

GitLeR, A. D. 2011. Another reason to exercise. Science 334:606-607.

HANNA, J. L. 1983. To dance is human, a theory of non-verbal communication. University of Texas Press, $327 \mathrm{pp}$.

HogAN, P. J. 2008. More evidence on value of dance. Aging and physical activity 16:435-445.

Jensvold, M. L. A., AND R. P. GaRDner. 2000. Interactive use of sign language by cross-fostered chimpanzees (Pan troglodytes). Journal of Comparative Psychology 114:335-346.

KAMINSKI, J., J. CALL, AND J. FISCHER. 2004. Word learning in a domestic dog: evidence for fast mapping. Science 304:1682-1683.

KING, B. J. 2009. The dynamic dance, non-vocal communication in African great apes. Harvard University Press. Cambridge, Massachuset and London, England.

Kotz, I. 2014. Bonobos, like humans, keep time to music. Ageing and Physical Activity 16:435-445. 
Large, E., and P. M. Gray. 2015. Spontaneous tempo and rhythmic entrainment in a bonobo (Pan paniscus). Journal of Comparative Psychology 29:317-328.

LAWLER, A. 2012. Uncovering civilizations roots. Science 335: 790-793.

LIDICKER, W. Z., JR. 2012. Which came first, music or dance? Let's Dance! (Folk Dance Federation of California) 69:13-14.

LoEWy, J. 2013. Premature babies and music. Pediatrics 162 (supplement 3 May): 902-918.

Margoliash, D., AND M. Hale. 2008. Vertebrate vocalizations. Science 321: 347-348.

Mingle, M. E., T. M. Eppley, M. W. Campbell, K. Hall, V. Horner, and F. B. DE WAAL. 2014. Chimpanzees prefer African and Indian music over silence. Journal of Experimental Psychology: Animal Learning and Cognition 40:502-505.

MITHIN, S. 2006. The singing Neanderthals: the origin of music, language, mind, and body. Harvard University Press. Cambridge, U.S.A.

Okobi, D. E., JR., A. Banerjee, A. M. M. Matheson, S. M. Phelps, and M. A. LoNG. 2019. Motor cortical control of vocal interaction in Neotropical singing mice. Science 363:983-988.

PenNISI, E. 2012. Preening the troops. Science 136:828.

Phillips-Silver, J., AND L. J. Trainor. 2005. Feeling the beat: movement influences infant rhythm perception. Science 308:1430.

POWERS, R. 2007. Dancing makes you smarter. Let's Dance! (Folk Dance Federation of California) Feb.: 12-13.

SARICH, C. 2013. Research links music to increased immunity and better mood. Natural society News 14 May: 1-2. http.// www.nationofchange.org/

SchellenBerG, E.G. 2004. Musiclessons enhance IQ. Psychological Science 15:511-514.

SPIRES-Jones, T. L., AND C. W. Ritchie. 2018. A mouse model of Alzheimer's disease provides clues about why exercise is good for memory. Science 361:975-976.

VERGHESE, J., ET AL. 2003. Leisure activities and the risk of dementia in the elderly. New England Journal of Medicine 348:25082516.

WILLIAMS, L. 1967. The dancing chimpanzee: study of primitive music in relation to vocalizing and rhythmic actions of apes. Norton, U.S.A.

Associated editor: Sergo Ticul Álvarez-Castañeda Submitted: July 15, 2019; Reviewed: August 7, 2019;

Accepted: August 8, 2019; Published on line: August 15, 2019. 